MAKÓ, Csaba - ILLÉSSY, Miklós -

- CSIZMADIA, Péter

\title{
MEASURING ORGANISATIONAL INNOVATION - THE EXAMPLE OF THE EUROPEAN COMMUNITY INNOVATION SURVEY (CIS)
}

In the last decade, non-technological and particularly organisational innovations have gained more and more importance and research focus. However, there is no consensus among the academic community either about the definition or about the broader theoretical and methodological foundations of this phenomena. In the present study the authors intend to partly improve this knowledge deficiency syndrome by analysing the most important theoretical contributions of organisational innovation and by reviewing the development in the methodological tools aimed to measure organisational innovation on a European level. By doing so, the authors will focus on the various waves of the Community Innovation Survey (CIS) as an employer-oriented and of the European Working Conditions Survey (EWCS) as an employee-oriented survey. Finally, they will formulate some remarks for further empirical research streams*.

Keywords: organisational innovation, survey methodology, competitiveness, work organisation, knowledge development practice of firms

In the last decade, innovation has become not only one of the most generally used "buzzword" or a "new hype" of policy makers in the developed countries, but there is a growing consent in the business and academic community that technological and non-technological innovations have a crucial role in a country's sustainable competitiveness and in creating new paths for economic development. The mainstream accounts of innovation deal predominantly with technological (product or process) innovation, neglecting the role and impacts of organisational innovation or socio-cultural changes as well as the social, cultural, psychological acceptance of new working practices and adaptation to them. This oversight is not just a feature of the Hungarian but also the European research and practice on innovation.

According to the European Competitiveness Report, the productivity growth advantage of the US over Europe is not just the consequence of higher standards of technological innovation. US companies are also at the forefront in terms of new organisational and management methods and governance. New business models, innovative supply methods, etc. play a key role in the introduction of technological innovations to new markets and in supporting entrepreneurship. Innovations referred to as non-technological (social-institutional) represent the "missing link" that hinders European companies in their exploitation of opportunities offered by new technologies and European integration. In this relation it is worth noting the decisive role of the workplace that is strongly influenced by the existing managerial and organisational practices. However, "The bottleneck in improving innovation capabilities of European firms might not lie in the low levels of R\&D expenditure, which are strongly determined by industry structures and therefore difficult to change, but the widespread existence of working environments that unable to provide fertile environment for innovation" (Arundel et al., 2006, cited by Alasoini, 2011b: p. 13.). 
Within the European countries we may identify visible differences in the distribution of such organisational forms or models that facilitate or constrain innovation or learning capabilities of firms. According to the 2005 data from the European Working Conditions Survey (EWCS), in comparison to the EU average, the Post-Socialist countries where work organisations with the greatest innovation and learning potential can be found are Estonia and Hungary. These two countries outperform the other Post-Socialist member states. Unfortunately, however, Taylorism/Fordism - the work organisation of mass production which has the lowest learning and innovation capability - also has a strong presence in these countries. The Hungarian economy, therefore, is characterised by a dual (asymmetric) model of work organisation: frontrunner companies (even measured by international standards) and companies with very restricted innovation and learning potential co-exist. Putting into the context of the
- Most Continental countries (Austria, Belgium, France and Germany): a less contrasting distribution of the different forms of work organisation and a slight overrepresentation of the discretionary learning forms. A midpoint situation is also observed in Hungary and Italy.

This model is aligned with the findings of other research results demonstrating that foreign companies and firms with mixed ownership are at the forefront of both technological and non-technological innovation. These firms emerge like cathedrals in the Hungarian economy. At the same time, fully Hungarian owned enterprises (primarily micro, small and medium-sized) pursue innovation activities of significantly less intensity (Dallago, 2010; Szerb, 2010; Chikán - Czakó Kazainé, 2006). Table 1 highlights the relation between firms' ownership and innovation performance.

Table 1

Ownership and Innovation Activity of Firms in the Hungarian Economy: 1999-2005*

\begin{tabular}{|l|c|c|c|c|}
\hline \multirow{2}{*}{ Ownership structure } & \multicolumn{3}{|c|}{ Share of innovative firms } \\
\cline { 2 - 5 } & \multicolumn{2}{|c|}{ Innovative firms } & \multicolumn{2}{c|}{ Non-innovative firms } \\
\cline { 2 - 5 } & $\mathbf{1 9 9 1 - 2 0 0 1} * *$ & $\mathbf{2 0 0 4 - 2 0 0 5 * * *}$ & $\mathbf{1 9 9 1 - 2 0 0 1 * *}$ & $\mathbf{2 0 0 4 - 2 0 0 5 * * *}$ \\
\hline 100\% Hungarian ownership & $13.4 \%$ & $17.3 \%$ & $84.9 \%$ & $82.7 \%$ \\
\hline Mixed-ownership & $31.5 \%$ & $30.5 \%$ & $65.8 \%$ & $69.5 \%$ \\
\hline $100 \%$ foreign ownership & $17.6 \%$ & $30.1 \%$ & $78.5 \%$ & $69.9 \%$ \\
\hline
\end{tabular}

EU-27 countries, the following six contrasting country profiles can be distinguished globally, according to the dominant model of work organisation ${ }^{1}$ :

- The Scandinavian countries of Denmark and Sweden, as well as the Netherlands: the discretionary learning forms of work organisation having high innovation capabilities predominate.

- The Anglo-Saxon countries (Ireland and the UK), some Eastern European countries (Estonia, Latvia, Poland and Slovenia), Finland, Luxemburg and Malta: characterised by a relatively high development of lean production work organisation forms. The discretionary learning forms are also slightly overrepresented in Finland, Luxemburg and Malta.

- Portugal and Romania: overrepresentation of lean production and Taylorist work organisation forms.

- Bulgaria and Slovakia: the Taylorist forms of work organisation are rather widely diffused.

- Certain Mediterranean countries (Cyprus, Greece and Spain) and some Eastern European countries (Czech Republic and Lithuania): an overrepresentation of the Taylorist and traditional or simple structure forms of work organisation.
" Technological "product" and "process" (TPP) innovation

** Iwasaki, I. (2004: 111. o.)

*** Calculation of Szunyogh Zsuzsa (Central Statistical Office, $\mathrm{KSH})$.

(Makó - Illéssy - Csizmadia, 2008: p. 1076.)

Unfortunately, a great majority of the Hungarian innovation research focuses on the diffusion of the technological product and process (TPP) innovations in the manufacturing sector. We already argued that nontechnological innovations also play a very important factor in a country's competitiveness. In addition, from the turn of the century, we assist a historical shift from the manufacturing to the service economy in the developed countries of Europe, Asia and America. This shift is well reflected by the share of the economic sectors in the structure of employment. Therefore there is a growing need to address the importance of non-technological innovation: "Information and communication technologies (ICT) sometimes presented as a phenomena that can completely replace human competence and interaction, through expert systems and internet connection. The belief in this myth has proven costly for firms and public authorities. All systematic empirical and historical research shows that an acceleration in the diffusion of 
a radically new technology results in more harm than benefits if it is not combined with new institutions, new modes of organization and new human competence" (Lundvall, 2002: p. 5.).

The structure of the paper is organised as follows: the first section gives a brief overview of the organisational surveys carried out mainly on an international level that are useful for cross-country comparisons. The second section focuses on the theoretical foundation (OSLO Manuals) and measuring tools of nontechnological innovations used in the various waves of the employer-oriented Community Innovation Survey (CIS) and presents Hungarian results on the diffusion of organisational innovation. This will be complemented with the experiences of the employee-focused European Working Condition Survey (EWCS). The final section discusses some critics of the concept of innovation adopted by the CIS and raises some issues for future research of social and organisational innovations.

\section{Benchmarking Exercise of the Organisational Surveys: European and National Perspective}

Although organisational innovation is rather a new phenomenon in the statistical data collection on a European level, the first systematic analysis of the organisational surveys was elaborated by Benjamin Coriat ${ }^{3}$.

Coriat distinguishes three groups of organisational surveys:

1) Seeking for some forms of division of labour and task coordination identified as representative forms of innovative working arrangements (e.g. teamwork, just-in-time, quality circles, etc.). This is typical of German questionnaires.

2) Seeking for organisational traits reflecting that the firm surveyed is innovative, i.e. it is capable of dynamically adjusting to the demands of the changing environment (intra-organisational and inter-organisational co-ordination methods). This is the case in Danish questionnaires.

3) A mixture of the two former groups (British and French cases).

The interpretation of data gathered by organisational surveys is a core issue. In relation to the methodology and the indicators used, Coriat raises four main problems:

1) The questions are mostly too general and thus the answers are too vague. How to interpret and compare, for example, the introduction of teamwork in a Swedish and in a Japanese working environment? "In the same way, it is also impossible to have any idea about the nature and contents of the learning processes that take place within working teams, since they largely vary according to how those teams are coordinated, about the levels of the tasks and responsibilities those teams are entrusted with, and about the way they are inter-related and their relationships with their hierarchies" (ib. id. p. 3.).

2) The mere existence of some organisational forms or practices does not permit to conclude that it works in an innovative way.

3) This leads us to the problem of defining organisational innovation and organisational change. The majority of the surveys detect only the latter without saying anything on the innovative characteristics, if any, of these organisational changes. "Indeed, the existence of such a process within a firm clearly testifies to changing organizational patterns, but nothing can be asserted as to the nature and orientation of those changes, or the new organizational patterns or traits themselves" (ib. id. p. 4.).

4) Level of novelty: in the surveys it is only possible to measure already well-known and codified working practices but it is impossible to measure the radically new ones unidentified by literature. This calls attention to the importance of such qualitative research methods as, for example, company case studies.

As it can be seen, different surveys work with different (although) implicit notions of organisational innovation. Is it possible to give one sole and explicit definition of organisational innovation? According to Coriat, it is difficult to define organisational innovation because of its "multidimensional character" and thus it can only be identified as a "joint group of attributes". This relates to the abovementioned categorisation of surveys aimed to measure organisational innovation: patterns of division of labour, specificity of coordination or a combination of these two. As Coriat puts it: "...if we consider that organizational innovation consists of a cluster of changes affecting the labour division and coordination patterns that prevail within a given organization (or between several organizations), these very patterns possessing a triple dimension (information, knowledge and know-how, interests $)^{4}$, we then understand what each one of the implicit concepts of organizational innovation captures, and the difficulty to interpret the result of the confrontation of the information delivered by each one" (ib. id. p. 6.).

According to Coriat, organisational surveys inform us on the presence or absence of these working arrangements and thus on the potential of any organisational innovation but the real content of these changes remain hidden. The analysis of different questionnaires does not give a definitive answer to the question of the difference between organisational change and organisational 
innovation. British surveys are agnostic as for the direction of organisational change and consequently any organisational change is considered as innovation. In contrast, Danish surveys implicitly suppose that organisational change can only be innovative if it leads to more flexibility (defined as "the dynamic capacity to adjust to changing environments", ib. id. p. 3.).

More recently, Ramioul and Huys made an inventory of the most significant organisational surveys of European countries, where the following selection principles were identified (Ramioul - Huys, 2007: p. 6.):

1) possibility to measure a wide range of topics covered by the organisational changes (e.g. innovation, working and employment conditions, labour relations, etc.), the selection principles presented above. These organisational surveys were carried out both on international and national level, and were characterised by a variety of methodological designs. In this respect the following four significant methodological orientations should be distinguished (Meadow, 2010: p. 10.):

1. Employer-focused survey,

2. Employee-focused survey,

3. Employer /employees survey (employer is sampled first-linked survey),

4. Employee/employer survey (employee is sampled first).

Table 2 summarises these surveys by their methodological orientation and time dimension.

Table 2

A Set of Possible Survey Designs (Meadow, 2010: p. 48.)

\begin{tabular}{|c|c|c|}
\hline Methodological orientation of the survey & Time dimension & Example of existing surveys \\
\hline \multirow[b]{2}{*}{ Employer only } & Cross section* & $\begin{array}{l}\text { CIS (Community Innovation Survey), ECS (European Company } \\
\text { Survey), ESWT (Establishment Survey on Working Time and Work- } \\
\text { Life Balance), EMS (European Manufacturing Survey). }\end{array}$ \\
\hline & Panel option ${ }^{* * *}$ & $\begin{array}{c}\text { DISKO (Danish Innovation System: Comparative analysis), OSA } \\
\text { Er (Labour demand panel -Arbeidsvraagpanel - The Netherlands), } \\
\text { NUTEK (Technological and Organisational Change and Labour } \\
\text { Demand ([Sweden]), PASO (Panel Survey of Organisations ([Flanders]) }\end{array}$ \\
\hline \multirow{2}{*}{ Employee only } & Cross section & $\begin{array}{c}\text { EWCS (European Working Conditions Survey), ESS (European Social } \\
\text { Survey), BSS (British Skills Survey) }\end{array}$ \\
\hline & Panel option & $\begin{array}{c}\text { NWCS (Netherlands Working Conditions Survey, OSA Ee [OSA } \\
\text { Labour supply panel - Arbeidsaanbodpanel]), }\end{array}$ \\
\hline \multirow{2}{*}{$\begin{array}{l}\text { Linked employer/employee } \\
\text { (or employer first approach) }\end{array}$} & Cross section & $\begin{array}{l}\text { COI (Changements Organisationels et Informatisation, France), ESES } \\
\text { (European Union Structure of Earnings Survey), MOA (The MOA } \\
\text { method for assessment of Organisation - Sweden), TNO/WIS (TNO } \\
\text { Work in the Information Society survey - the Netherlands), }\end{array}$ \\
\hline & Panel option & $\begin{array}{l}\text { LIAB (Institute für Arbeits- und Berufsforschung - IAB-Germany), } \\
\text { RESPONSE (Relations professionnelles et negotiations d'entreprise- } \\
\text { France), WES (Workplace and Employee Survey - Canada), WERS } \\
\text { (Workplace Employment Relations Survey - UK)**** }\end{array}$ \\
\hline \multirow[t]{2}{*}{$\begin{array}{l}\text { Linked employee/employer } \\
\text { (or employer first approach) }\end{array}$} & Cross section & $\begin{array}{c}\text { AES-CVTS (Adult Education Survey - Continuing Vocational Training } \\
\text { Survey - France), EFE (Enquete famille employeurs - France), NOS } \\
\text { (National Organization Study - USA). }\end{array}$ \\
\hline & Panel option & \\
\hline
\end{tabular}

2) scope: the organisational survey must cover a wide range of sectors, preferably the structure of the whole economy,

3) periodicity: the organisational surveys must be carried out in several waves over years applying the same or similar questions.

In the framework of a recent international project aimed to collect and interpret information on the process of organisational changes in the last two decades, twenty organisational surveys were carried out covering
* Cross section survey: measuring change by retrospective questions.

* Panel survey: measuring change through repeated measurements.

*** The methodology of the first Hungarian Employment Survey (2010) adopted the approach of the British WERS (Workplace Employment Relation Survey), carried out in the following waves: 1980, 1984, 1990, 1998 and 2004. (See in detail: http:// www.wers2004.info/index.php). The highlighted surveys are cross-national, NOS and WES are national (North America), PASO is regional (Flemish region) and the other surveys are national (European countries). 
Table 3 classifies the seven European organisational surveys from the total twenty one (international \& national) according to their acronym, name, last wave of survey and producer/sponsor.
Hungarian firms participating in several waves of the survey. Due to the fact that the CIS is an employeroriented survey, we use empirical experiences from an employee-oriented survey. For this purpose, results of

Main Characteristics of the European Organisation Surveys (Meadow, 2010: p. 91-92.)

\begin{tabular}{|c|c|c|c|c|}
\hline Acronym & Name of the survey & Last wave & Countries covered & Producer/sponsor \\
\hline CIS (employer) & $\begin{array}{c}\text { Community Innovation } \\
\text { Survey }\end{array}$ & CIS-2010 & $\begin{array}{l}\text { EU-27, Iceland, Norway and } \\
\text { Turkey }\end{array}$ & Eurostat \\
\hline ECS (employer & $\begin{array}{l}\text { European Company } \\
\text { Survey }\end{array}$ & 2009 & $\begin{array}{l}\text { EU-27 + Croatia, Turkey and } \\
\text { Former Yugoslav Republic } \\
\text { of Macedonia (FYROM) }\end{array}$ & $\begin{array}{l}\text { European Foundation for the } \\
\text { Improvement of Living and Working } \\
\text { Conditions (EFLWC) }\end{array}$ \\
\hline EMS (employer) & $\begin{array}{l}\text { European Manufacturing } \\
\text { Survey }\end{array}$ & 2006 & $\begin{array}{l}\text { Germany, Austria, Croatia, } \\
\text { France, UK, Italy, Slovenia, } \\
\text { Turkey, Greece, Netherlands } \\
\text { and Spain }\end{array}$ & $\begin{array}{l}\text { Coordinator: Fraunhofer Institute of } \\
\text { Systems and Innovation Research } \\
\text { (ISI) }\end{array}$ \\
\hline $\begin{array}{c}\text { ESES (linked } \\
\text { employer/employee }\end{array}$ & $\begin{array}{l}\text { European Union } \\
\text { Structure of Earnings } \\
\text { Survey }\end{array}$ & 2006 & $\begin{array}{c}\text { EU-27 + Iceland and } \\
\text { Norway }\end{array}$ & Eurostat \\
\hline $\begin{array}{l}\text { ESS (persons over } \\
15 \text { years old in } \\
\text { private households) }\end{array}$ & European Social Survey & $2006 / 2007$ & $\begin{array}{c}32 \text { countries, including } 22 \\
\text { EU countries }\end{array}$ & $\begin{array}{l}\text { Coordinator: City University, UK., } \\
\text { University Leuven, Belgium, NSD, } \\
\text { Norway, ZUMA Germany, ESADE, } \\
\text { Spain, Netherlands Sponsored by } \\
\text { the European Commission and the } \\
\text { European Science Foundation }\end{array}$ \\
\hline ESWT (employer) & $\begin{array}{l}\text { Establishment Survey } \\
\text { on Working Time and } \\
\text { Work-Life Balance }\end{array}$ & 2010 & $\begin{array}{l}\text { EU-15 and Czech Republic, } \\
\text { Cyprus, Hungary, Latvia, } \\
\text { Poland, Slovenia }\end{array}$ & $\begin{array}{l}\text { European Foundation for the } \\
\text { Improvement of Living and Working } \\
\text { Conditions (EFILWC) }\end{array}$ \\
\hline EWCS (employee) & $\begin{array}{l}\text { European Working } \\
\text { Conditions Survey }\end{array}$ & 2010 & $\begin{array}{l}\text { EU-27 + Croatia, Turkey, } \\
\text { Switzerland and Norway }\end{array}$ & $\begin{array}{l}\text { European Foundation for the } \\
\text { Improvement of Living and Working } \\
\text { Conditions (EFILWC) }\end{array}$ \\
\hline
\end{tabular}

Comparing the design and structure of surveys presented in Table 3 above, we may distinguish two forms of co-ordination. In the first case, the survey is designed and implemented centrally (e.g. the European Working Conditions Surveys). In the second case, the survey is carried out in a decentralised way. For example, the 2004 decree of the European Commission (1450/2004/EC) is an obligatory regulation for member states to carry out the Community Innovation Survey. Eurostat is responsible for the co-ordination of surveys in close co-operation with the National Statistical Offices that are responsible for the national design, fieldwork and data analysis in every four or two (light surveys) years.

The next section presents the brief history of the European innovation statistics with a special focus on the elaboration of questions aimed to measure various dimensions of organisational innovation. Besides mapping organisational innovation related questions of the CIS, this section will give a brief overview on the importance of organisational innovations of the the various waves of the European Working Conditions Surveys (EWCS) on the learning and innovative character of the work organisation of Hungarian firms will be presented through an international comparison.

\section{Attempts to Measure Organisational Innovation: Case of the European Innovation Survey (CIS)}

\section{From Narrow to the Broadening Views of Innovation}

Building on the innovation theory of Schumpeter $(1950,1966)$ and stressing his so-called Mark II. period on the importance of co-operation and collective efforts in producing innovation (in contrast to the key role of the individual entrepreneurs (Mark I. period), we may assert the outcomes of innovation research "...that a firm does not innovate in isolation but depends on extensive interaction with its environment. Various concepts have been introduced to enhance our understanding of 
this phenomenon, most of them including the terms "system" or the somewhat less ambitious "network" (Fagerberg, 2006: p. 20.). In recent years, the broadening view of innovation is characterising public thinking and innovation has become one of the most extensively used "catch-word" even among policy makers. For example, the Finnish national innovation strategy elaborated half a decade ago (2008), “... is based on the idea that the focus of innovation policy should be shifted increasingly to demand and user-driven innovations and the promotion of non-technological innovations" (Alasoini, 2011a: p. 23-24.). Besides such features of innovation as radical versus incremental, product versus process, open or disruptive, social and organisational innovation, etc., we intend to stress those theoretical concepts that question the validity of unidirectional approaches where innovation is shaped by one single group of factors (e.g. "science push" or "demand pull" views of innovation). In this perspective, not only the "locus" of innovation is changing (e.g. increasing role of clients/customers, suppliers, growing importance of environmental protection, shift from manufacturing to service sector, etc.) but the "focus" too. In this relation, we share the following statement: "... when we think about the changing focus of innovation, the issue is less one of a move away from conventional technological innovation to a much more thorough understanding of how technological and social change are both required for service innovation. This itself requires some rethinking of management practice and policy development; but such a shift in focus is required if the objectives of innovation efforts are to be focused more on meeting Grand Challenges" (Basset - Miles - Thénint, 2011: p. 5.).

One of the most important "Grand Challenges" is the historical shift from manufacturing to the service economy. From the last decades of the $20^{\text {th }}$ century, we have assisted an unprecedented growth of the service sector at the expense of the manufacturing and agricultural sectors. Some service sector scholars call this radical shift in the economic activities the "service sector revolution". In the developed countries this sector produces $70-80 \%$ of GDP, while in the Post-Socialist countries of Central and Eastern Europe the share of service sector ranges from $58.4 \%$ to $62.9 \%$. It is worth mentioning that in the case of Hungary between 1992 and 2006, the productivity growth in the service sector (measured by the share of the gross value added/ capital) was higher than in the manufacturing sector. In addition, the service sector played a crucial role in employment generation too. Between 1995 and 2006 every second new job (46\%) was created in the service sector and, interestingly enough, more than every second new job (57\%) was established in the KnowledgeIntensive Business Services (KIBS) (Makó - Csizmadia - Illéssy - Iwasaki - Szanyi, 2011).

This radical change in the economic structure raises the methodological problem of how to measure innovation in this sector. Some groups of scholars stress the difference between innovation realised in the manufacturing and in the service sectors. On the contrary, others tend to apply methods and knowledge accumulated on innovation in the manufacturing sector to the service sector: this is the so-called assimilation view. However, the boundaries between the two sectors have been diminishing and "a newly proposed synthesis approach" (Miles - Boden, 2000) argues that studies conducted on service sector innovation are capable of broadening our understanding of innovation that is currently shaped by the traditional focus on manufacturing innovation (Beyhan et al., 2009: p. 4.). One of the most important lessons learned from this debate is that besides the discussion on how to improve statistical tools and other metrics, we have to reposition our interest to better understand the features of non-technological innovation, in spite of the fact that "this may not rely on conventional R\&D, nor be manifest in new ideas that can be protected by the patent measures" (Basset - Miles - Thénint, 2011: p. 9.).

Adopting the broadest view of organisational innovation according to which "...the term 'organisational innovation' refers to the creation or adoption of an idea or behaviour new to the organisation" (Lam, 2005: p. 115.), we intend to analyse the theoretical foundations and empirical experiences of the development of statistical methods measuring organisational innovation on a European level. For this purpose, the next section focuses on changes in the guidelines of the Oslo Manual on various forms of innovation, with special attention to the organisational ones and their measurement in the various waves of the Community Innovation Survey (CIS) from 1993 until today. As the CIS is an employer-oriented survey, we intend to complete its results with the experiences of the employee-oriented European Working Condition Survey (EWCS).

\section{Designing Questions to Measure Organisational Innovation: The Experiences of the European Community Innovation Survey (CIS)}

From the end of the Second World War until the end of the 1970's, international surveys focused exclusively on data collection of the well-known Research and Development (R\&D) activities. It required more than a decade of preparation co-ordinated by the OECD and empirical experiences learned from the pilot stud- 
ies carried out mainly in the Nordic countries, before the first edition of the so-called Oslo Manual was published in 1992. This manual became the theoretical and methodological foundation of the European Community Innovation Survey (CIS). Until now, six waves of the CIS have been prepared. Table 4 summarises the most important characteristics of these surveys.
Oslo Manual (1997) provided guidelines for both manufacturing and service sector activities. Unfortunately, the TTP approach used in this version of the Manual could not properly measure the particular characters of the service sector. It was only the third edition of the Oslo Manual (2005) that aimed to measure not only TPP innovation but marketing and organisational in-

History of the CIS and Organisational Innovation (Arundel, 2010:1)

\begin{tabular}{|c|c|c|c|}
\hline Survey & Survey year & Reference date* & Organisational innovation questions \\
\hline CIS-1 & 1993 & $1990-1992$ & None \\
\hline CIS-2 & 1997 & 1994-1996 & None \\
\hline CIS-3 & 2001 & $1998-2000$ & $\begin{array}{l}\text { Whether the enterprise introduced a new or significantly changed: } \\
\text { 1. Corporate strategy } \\
\text { 2. Advanced management technique } \\
\text { 3. Organisational structure }\end{array}$ \\
\hline CIS-4 & 2005 & $2002-2004$ & $\begin{array}{l}\text { Whether the enterprise introduced a new or significantly changed: } \\
\text { 1. Knowledge management system } \\
\text { 2. Change to the organisation of work } \\
\text { 3. Change to relations with other firms } \\
\text { Four types of effects of organisational innovation: } \\
\text { 1. Reduced time to respond to customer needs } \\
\text { 2. Improved quality of goods or services } \\
\text { 3. Reduced costs per unit output } \\
\text { 4. Improved employee satisfaction }\end{array}$ \\
\hline CIS 2006 & 2007 & 2004-2006 & $\begin{array}{l}\text { Identical questions as in the CIS-4. New questions tested in an extended version } \\
\text { of the CIS-2006, a pilot survey version, utilising face-to-face interviews. }\end{array}$ \\
\hline CIS 2008 & 2009 & $2006-2008$ & Identical questions as in the CIS-6. \\
\hline
\end{tabular}

* Questions refer to organisational innovations introduced during this time period.

In relation to the waves of the CIS, Arundel (2010: p. 2.) indicated that in spite of the fact that the CIS2006 adopted the same questionnaire that was used in the CIS-4, several additional questions were tested: "who developed" organisational innovation, the type of organisational innovation (new business practices) and the "effects" of innovation (improved communication or information sharing). It is worth noting that in the case of the CIS survey the Central Statistical Office of each participating country has to prepare a so-called Quality Report for the country concerned.

The first edition of the Oslo Manual dealt mainly with the technological product and process (TPP) innovations in the manufacturing sector. These measurement tools were not designed to evaluate and map service sector innovation despite of the fast growing importance of this economic sector. The Oslo Manual (1992) served as a guideline for such large scale surveys as the CIS aimed to measure factors shaping both innovation and their impacts. The second edition of the novation as well. An innovation, according to this version of the Oslo Manual " ... is the implementation of a new or significantly improved product (goods or services), or process, a new marketing method, or a new organisational method in business practices, workplace organisation or external relations" (Oslo Manual, 2005: p. 46.). The four types of innovations are the following (Oslo Manual, 2005: p. 46-51.):

1) A product innovation is the introduction of goods or services that are new or significantly improved with respect to their characteristics or intended use. This includes significant improvements in technical specifications, components and materials, incorporated software, user-friendliness or other functional characteristics.

2) A process innovation is the implementation of new or significantly improved production or delivery methods. This includes significant changes in techniques, equipment and software.

3) A marketing innovation is the implementation of a new marketing method involving significant chang- 
es in product design or packaging, product placement, product promotion or pricing.

4) An organisational innovation is the implementation of a new organisational method in the firms' business practices, workplace organisation or external relations.

Due to the core interest of the present study, in the following section we intend to focus on the questions designed to identify the various forms of organisational innovations and their impacts. For illustrative purposes, we choose the latest wave of the CIS-10 (covering the period of 2008-2010) in which the following questions measured organisational innovation.

\section{Q 9. Organisational Innovation}

An organisational innovation is a new organisational method in your enterprise's business practices (including knowledge management), workplace organisation or external relations that has not been previously used by your enterprise.

- It must be the result of strategic decisions taken by management.

- Exclude mergers or acquisitions, even if for the first time.

\section{Q. 9.1 During the three years 2008 to 2010 , did your enterprise introduce:}

Following a historical overview of the waves of the CIS and a revision of the questions elaborated with the aim to identify both the forms and the effects of organisational innovations, some empirical data on trends will be presented related to innovation in the Hungarian economy. Table 3 indicated that the CIS survey was an employer-oriented type of survey, therefore it would be beneficial to complete the empirical experiences of the CIS with an employee-oriented type of survey. In order to do so, we will use the results of the European Working Conditions Survey (EWCS). In the next section, combining the empirical information collected from both employers and employees, we may get a more balanced view on the trends and intensity of organisational innovation of firms operating in Hungary. ${ }^{5}$

\section{Organisational Innovation \\ in the Hungarian Context: Some Lessons from the CIS and the EWCS}

By analysing the results of the surveys, we may identify the following international pattern in general: the intensity of innovation increases with the size of the firm. For example, a great majority of small enterprises (10-49 employees) did not implement any types of organisational and marketing innovations (see Table 5). In contrast, almost every second large firm implemented organisational and marketing innovations. The other pattern observed between the period of the CIS- 6

\begin{tabular}{|l|l|}
\hline & Yes \\
\hline $\begin{array}{l}\text { New business practices for organising procedures (i.e. supply chain management, business re-engineering, } \\
\text { knowledge management, lean production, quality management, etc.) }\end{array}$ & $\square \quad \square \quad \begin{array}{l}\text { New methods of organising worker responsibilities and decision making (i.e. first use of a new system of } \\
\text { employee responsibilities, team work, decentralisation, integration or de-integration of departments, education/ } \\
\text { training systems, etc.) }\end{array} \quad \begin{array}{l}\text { New methods of organising external relations with other firms or public institutions (i.e. first use of alliances, } \\
\text { partnerships, outsourcing or sub-contracting, etc.) }\end{array}$ \\
\hline
\end{tabular}

Q. 9.2 How important were each of the following objectives for your enterprise's organisational innovations introduced during the three years 2008 to 2010 inclusive? and CIS- 8 is that the share of these types of innovations has declined. The decrease of innovation activity was higher than the average especially in the category of small firms.

\begin{tabular}{|l|c|c|c|c|}
\hline \multicolumn{3}{|c|}{ If your enterprise introduced several organisational innovations, make an overall evaluation } \\
\hline & High & Medium & Low & Not relevant \\
\hline Reduce time to respond to customer or supplier needs & $\square$ & $\square$ & $\square$ & $\square$ \\
\hline Improve ability to develop new products or processes & $\square$ & $\square$ & $\square$ & $\square$ \\
\hline Improve quality of your goods or services & $\square$ & $\square$ & $\square$ & $\square$ \\
\hline Reduce costs per unit output & $\square$ & $\square$ & $\square$ & $\square$ \\
\hline $\begin{array}{l}\text { Improve communication or information sharing within your enterprise or with } \\
\text { other enterprises or institutions }\end{array}$ & $\square$ & $\square$ & $\square$ & $\square$ \\
\hline
\end{tabular}


Relation Between the Firm's Size and All Types of Organisational (Including Marketing) Innovation in Hungary

(Community Innovation Survey, CIS-4, CIS-6 and CIS-8)

\begin{tabular}{|l|c|c|c|}
\hline Firm's size & CIS-4 (2002-2004) & CIS-6 (2004-2006) & CIS-8 (2006-2008) \\
\hline $10-49$ employees & $15 \%$ & $16.5 \%$ & $10.7 \%$ \\
\hline $50-249$ employees & $28.6 \%$ & $24.9 \%$ & $19.8 \%$ \\
\hline 250 and over & $46.1 \%$ & $49.0 \%$ & $45.3 \%$ \\
\hline Total: & $18.3 \%$ & $18.9 \%$ & $13.3 \%$ \\
\hline
\end{tabular}

Note: Data based on the calculation of Zsuzsa Szunyogh, Deputy Head of Division, Central Statistical Office (KSH).

Dealing with the trends and intensity of "organisational innovation only", we may say that firms rather rarely rely on organisational development (from $4.1 \%$ to $13.1 \%$ ) to improve their daily operations. The other interesting pattern is that the decreasing intensity of organisational innovation has started in the CIS-4 (20022004). Between the CIS- 6 and the CIS-8, the already rather modest share of organisational innovation halved within the group of the small firms $(8.8 \%$ vs. $4,1 \%)$ and almost halved in the category of the medium-sized firms (8.4\% vs. 5.5\%) surveyed (Table 6). ing Conditions Surveys (EWCS) are particularly suggestive. ${ }^{7}$ Among the numerous questions aimed to measure the characteristics of working practices, we intend to assess the results of the questions related to the "cognitive dimension" of jobs (i.e. learning new things at work, job rotation requiring different skills, autonomy in quality supervision) and forms of training (i.e. "formal" versus "on-the-job training") in the EU27 countries. This job characteristic is indicating the learning potential of the firm having direct impacts on its innovation performance. In making cross-country comparison and applying an aggregated category as the EU-27 countries, we intend to compare the results of the above mentioned dimensions of working practices

Table 6

\section{Relations between Organisational Innovation Only /All Firms in Hungary}

(Community Innovation Survey, CIS-4, CIS-6 and CIS-8)

\begin{tabular}{|l|c|c|c|}
\hline \multicolumn{1}{|c|}{ Firm's size } & CIS-4 (2002-2004) & CIS-6 (2004-2006) & CIS-8 (2006-2008) \\
\hline $10-49$ employees & $8.8 \%$ & $8.8 \%$ & $4.1 \%$ \\
\hline $50-249$ employees & $13.1 \%$ & $8.4 \%$ & $5.5 \%$ \\
\hline 250 and over & $11.3 \%$ & $10.8 \%$ & $7.4 \%$ \\
\hline Total: & $9.5 \%$ & $8.8 \%$ & $4.5 \%$ \\
\hline
\end{tabular}

Note: The table based on the calculation of Zsuzsanna Szunyogh, Deputy Head of Division, Central Statistical Office (KSH).

This is rather an internationally well-known pattern. Organisational changes and innovation are varying substantially by size-category of the firms. For example, according to the statistically best documented Danish company practice survey $\left(\mathrm{DISKO}^{6}\right)$, organisational changes (innovation) are rather frequent in large firms: nine out of every ten firms - with more than $100 \mathrm{em}$ ployees - have carried out organisational changes in one or both periods of the surveys. Among small firms - with less than 50 employees - almost every second $(46 \%)$ did not introduce any organisational change.

It is worth noting the innovation propensity of firms using the results of the employee-oriented surveys. The results of the last three waves of the European Work- according to the following country profiles reflecting the varieties of the social welfare models within the European countries:

1. Nordic countries,

2. Continental countries,

3. Anglo-Saxon countries,

4. Mediterranean countries,

5. Post-Socialist countries.

Comparing the cognitive dimension of jobs in the EU-27 countries, we may say that countries belonging to the Nordic-country cluster perform visibly better than the EU average in all respects: at least 4 employees out of 5 can learn new things at work, have autonomy to assess quality and every second of them participate in tasks rotation requiring different skills. The Post-Social- 
ist countries are on the other extreme pole of the country groups, where each cognitive dimension of the jobs has a lower value than the EU-27 average. This country group is followed by the Mediterranean countries that have a rather similar pattern of job characteristics. In addition, we have to indicate the declining importance of the "job rotation requiring different skills" ("multi tasking and multi-skilling") in the Post-Socialist countries in comparison not only with the Nordic countries but with the EU-27 average: less than one-third of these employees rotate jobs, as shown in Table 7. The AngloSaxon and the Continental countries occupy the middle position between the Nordic and the Mediterranean / Post-Socialist country groups. ever, as highlighted in Table 8, following a decline in the intensity of participation in formal training in the Post-Socialist countries between 2000 and 2005 (30.6\% in 2000 versus $25.4 \%$ in 2005 ), this country group did improve its position remarkably from 2005 to 2010 (25.4\% in 2005 versus $34.8 \%$ in 2010 ). Another interesting pattern to note is the importance of the "informal training" or "situated learning". This kind of training represents the same share as the formal training and its importance has increased in the last half decade. Once again, the highest share of formal and informal training - almost every second employees surveyed - was registered in the Nordic countries. In this relation it is necessary to note that

Table 7

The Cognitive Dimension of Jobs: EU-27 versus Nordic and Post-Socialist Country Groups (2000-2010)

\begin{tabular}{|l|c|c|c|c|c|c|c|c|c|}
\hline \multirow{2}{*}{ Features of job } & \multicolumn{3}{|c|}{$\mathbf{2 0 0 0}$} & \multicolumn{2}{|c|}{$\mathbf{2 0 0 5}$} & \multicolumn{2}{|c|}{2010} \\
\cline { 2 - 10 } & EU-27 & $\begin{array}{c}\text { Nordic } \\
\text { countries }\end{array}$ & $\begin{array}{c}\text { Post- } \\
\text { Socialist } \\
\text { countries }\end{array}$ & EU-27 & $\begin{array}{c}\text { Nordic } \\
\text { countries }\end{array}$ & $\begin{array}{c}\text { Post- } \\
\text { Socialist } \\
\text { countries }\end{array}$ & EU-27 & $\begin{array}{c}\text { Nordic } \\
\text { countries }\end{array}$ & $\begin{array}{c}\text { Post- } \\
\text { Socialist } \\
\text { countries }\end{array}$ \\
\hline $\begin{array}{l}\text { Self-assessment of } \\
\text { quality }\end{array}$ & $73.4 \%$ & $\mathbf{8 2 . 8 \%}$ & $63.9 \%$ & $71.9 \%$ & $\mathbf{7 8 . 7 \%}$ & $63.5 \%$ & $72.8 \%$ & $\mathbf{8 2 . 9 \%}$ & $63.5 \%$ \\
\hline $\begin{array}{l}\text { Learning new things } \\
\text { at work }\end{array}$ & $69.9 \%$ & $\mathbf{8 4 . 7 \%}$ & $66.8 \%$ & $69.9 \%$ & $\mathbf{8 7 . 4 \%}$ & $67.4 \%$ & $68.0 \%$ & $\mathbf{8 6 . 3 \%}$ & $66.7 \%$ \\
\hline $\begin{array}{l}\text { Tasks rotation that } \\
\text { require different } \\
\text { skills }\end{array}$ & n.d. & n.d. & n.d. & $33.7 \%$ & $\mathbf{5 2 . 1 \%}$ & $32.8 \%$ & $34.0 \%$ & $\mathbf{5 4 . 1 \%}$ & $27.2 \%$ \\
\hline
\end{tabular}

Company Training Practice: EU-27 versus Nordic and Post-Socialist Countries

Table 8 . (2000-2010)

\begin{tabular}{|l|c|c|c|c|c|c|c|c|c|}
\hline & \multicolumn{3}{|c|}{$\mathbf{2 0 0 0}$} & \multicolumn{3}{|c|}{$\mathbf{2 0 0 5}$} & \multicolumn{2}{c|}{2010} \\
\cline { 2 - 9 } & EU-27 & $\begin{array}{c}\text { Nordic } \\
\text { countries }\end{array}$ & $\begin{array}{c}\text { Post- } \\
\text { Socialist } \\
\text { countries }\end{array}$ & EU-27 & $\begin{array}{c}\text { Nordic } \\
\text { countries }\end{array}$ & $\begin{array}{c}\text { Post- } \\
\text { Socialist } \\
\text { countries }\end{array}$ & EU-27 & $\begin{array}{c}\text { Nordic } \\
\text { countries }\end{array}$ & $\begin{array}{c}\text { Post- } \\
\text { Socialist } \\
\text { countries }\end{array}$ \\
\hline $\begin{array}{l}\text { Training paid by the } \\
\text { employer }\end{array}$ & $29.3 \%$ & $\mathbf{4 7 . 8 5 \%}$ & $30.6 \%$ & $26.24 \%$ & $\mathbf{4 2 . 9 \%}$ & $25.4 \%$ & $33.8 \%$ & $\mathbf{4 8 . 1 3 \%}$ & $34.8 \%$ \\
\hline $\begin{array}{l}\text { On-the-job training } \\
\text { (OJT) }\end{array}$ & n.d. & n.d. & n.d. & $26.3 \%$ & $\mathbf{4 1 . 3 3 \%}$ & $28.6 \%$ & $32.3 \%$ & $\mathbf{4 8 . 1 3 \%}$ & $34.0 \%$ \\
\hline
\end{tabular}

Besides the cognitive characteristics of the jobs, the importance and structure of training or skill/knowledge formation indicates the learning/innovation capacity of an organisation. In this relation, again, it is worth noting the leading-edge position of the Nordiccountry group: the share of employees participating in (formal) training paid by the employer is significantly higher in this country group in comparison to both the EU-27 average and the Post-Socialist countries. How- the OJT (informal or situated learning) knowledge development practice evolved faster in the Post-Socialist countries than in the EU-27 countries. The share of employees paying for their training has increased in all country groups between 2005 and 2010 (no EWCS 2000 data is available on training paid by employees and on-the-job training).

The final chapter of the study focuses on the diffusion of organisational innovation and knowledge de- 
Cognitive Dimension of Jobs: Post-Socialist Countries versus Hungary and Slovakia

(2000-2010)

\begin{tabular}{|l|c|c|c|c|c|c|c|c|c|}
\hline \multirow{2}{*}{ Features of job } & \multicolumn{3}{|c|}{$\mathbf{2 0 0 0}$} & \multicolumn{2}{|c|}{$\mathbf{2 0 0 5}$} & \multicolumn{2}{c|}{2010} \\
\cline { 2 - 10 } & $\begin{array}{c}\text { Post- } \\
\text { Socialist } \\
\text { countries }\end{array}$ & Hungary & Slovakia & $\begin{array}{c}\text { Post- } \\
\text { Socialist } \\
\text { countries }\end{array}$ & Hungary & Slovakia & $\begin{array}{c}\text { Post- } \\
\text { Socialist } \\
\text { countries }\end{array}$ & Hungary & Slovakia \\
\hline $\begin{array}{l}\text { Self-assessment of } \\
\text { quality }\end{array}$ & $\mathbf{6 3 . 9 \%}$ & $43.3 \%$ & $60.6 \%$ & $\mathbf{6 3 . 5 \%}$ & $48.3 \%$ & $52.2 \%$ & $\mathbf{6 3 . 5 \%}$ & $43.0 \%$ & $60.3 \%$ \\
\hline $\begin{array}{l}\text { Learning new things } \\
\text { at work }\end{array}$ & $66.8 \%$ & $57.9 \%$ & $\mathbf{6 7 . 2 \%}$ & $\mathbf{6 7 . 4 \%}$ & $58.9 \%$ & $67.1 \%$ & $\mathbf{6 6 . 7 \%}$ & $63.7 \%$ & $64.0 \%$ \\
\hline $\begin{array}{l}\text { Tasks rotation that } \\
\text { require different skills }\end{array}$ & n.d. & n.d. & n.d. & $32.8 \%$ & $15.6 \%$ & $\mathbf{3 8 . 2 \%}$ & $27.2 \%$ & $17.5 \%$ & $\mathbf{3 3 . 6 \%}$ \\
\hline
\end{tabular}

Company Training Practice: Post-Socialist Countries versus Hungary and Slovakia

Table 10

$(2000-2010)$

\begin{tabular}{|c|c|c|c|c|c|c|c|c|c|}
\hline \multirow[b]{2}{*}{ Features of job } & \multicolumn{3}{|c|}{2000} & \multicolumn{3}{|c|}{2005} & \multicolumn{3}{|c|}{2010} \\
\hline & $\begin{array}{c}\text { Post- } \\
\text { Socialist } \\
\text { countries }\end{array}$ & Hungary & Slovakia & $\begin{array}{c}\text { Post- } \\
\text { Socialist } \\
\text { countries }\end{array}$ & Hungary & Slovakia & $\begin{array}{c}\text { Post- } \\
\text { Socialist } \\
\text { countries }\end{array}$ & Hungary & Slovakia \\
\hline $\begin{array}{l}\text { Training paid by the } \\
\text { employer }\end{array}$ & $30.0 \%$ & $25.2 \%$ & $40.2 \%$ & $25.4 \%$ & $15.7 \%$ & $33.9 \%$ & $34.8 \%$ & $27.7 \%$ & $36.2 \%$ \\
\hline $\begin{array}{l}\text { On-the-job training } \\
\text { (OJT) }\end{array}$ & n.d. & n.d. & n.d. & $28.6 \%$ & $18.6 \%$ & $47.4 \%$ & $34.0 \%$ & $28.3 \%$ & $50.5 \%$ \\
\hline
\end{tabular}

velopment practices comparing Hungarian and Slovak firms operating in the so-called Knowledge-Intensive Business Service sector (KIBS). As shown in Table 9, in each cognitive dimension of jobs Slovakia holds a better position than Hungary. In relation to "selfassessment of quality" and "learning new things at work", Slovakia performs around the average of the Post-Socialist countries. In the case of the "job rotation requiring different skills" dimension, Slovakia outperforms the country group of the Post-Socialist countries (38.2\% versus $32.8 \%$ in 2005 and $33.6 \%$ versus $27.2 \%$ in 2010).

In relation to company training practices, detailed in Table 10, we may say that the share of employees participating in formal training paid by the employers and especially the importance of informal training (on-the-job training - OJT) is remarkably higher in the case of Slovak firms compared to the Post-Socialist country group average and notably to Hungarian firms. Finally, it is worth mentioning that the share of informal training in these two countries - particularly in Slovakia - is higher in comparison to formal training. Both in the EU-27 and the Post-Socialist countries the share of formal and informal trainings is rather balanced.
Finally, it is worth noting that following the international financial and economic crisis (2007-2009) the share of both formal and informal trainings in Slovakia is similar or slightly higher than in the EU-27 country group average and that the share of employees participating in informal training is higher in Slovakia than in the Nordic country group.

\section{Further Challenges in Measuring Organistional Innovations: Some Remarks}

In spite of the core importance of organisational innovation in exploiting the potentials of other types of innovation (e.g. TPP), a generally accepted and consistent theoretical framework does not exist in the literature of organisational innovation. Due to the underdeveloped theoretical and methodological foundations, a generally accepted definition of this type of innovation does not prevail. The concepts and views of the following theoretical schools shape the various definitions of organisational innovation (Lam, 2005: p. 116.):

1. Organisational design theory: this orientation focuses on the interrelation between structural forms and the willingness of an organisation to innovate. 
2. Organisational cognition and learning: this strand of literature deals with the capacity of organisations to explore and exploit new knowledge necessary to innovate.

3. Organisational change and adaptation: this approach examines the firms' capacity/capability to develop adequate answers to changes in external environment and how to influence it.

Another major weakness in the general definition of innovation - and especially in the case of organisational innovation - is "...to treat innovation as if it was a well-defined, homogeneous thing that could be identified as entering the economy at a precise date or becoming available at a precise point in time ... The fact is that the most important innovations go through drastic changes in their lifetimes" (Fagerberg, 2006: p. 5.). In other words, the instruments (i.e. questionnaire) designed to identify or map the various types of innovation (including organisational innovation) do not realise the "continuous" character of innovation.

In addition, Coriat (2001) stresses the following weaknesses of survey methods aimed to identify and assess organisational innovation:

1) The definitions (implicit or explicit) used in surveys "do not generally encompass the whole dimension" of organisational innovations.

2) It is important to investigate the direction of organisational innovation because the most radical organisational changes themselves may lead to reproduce the Taylorist principles of work organisations.

3) European companies are engaged in implementing organisational innovation that results in a "self-fuelled dynamism". However, there remains many possibilities to foster this process partly by public policies which have been so far mainly concerned by technological innovation.

4) Organisational innovation always results in a better organisational performance and organisational efficiency influencing both the cost and non-cost related competitiveness of firms.

5) A more systematic comparison is needed between the theory of organisational innovation and the empirical results.

6) There is a contradiction between the obvious advantages offered by organisational innovation and the relative slowness of their diffusion. This can be explained by objective and subjective factors (i.e. the intensity of change in the environment varies by regions, sectors, etc., while the subjective dimension means the ability of firms to perceive changes and the necessity to react to them). Another factor contributing to the low rate of diffusion of organisational innovation is that the knowledge and know-how in this field is poorly codified with the exception of the most widespread organisational standards like ISO and just-in-time, to some extent. Finally, organisational innovations generally reshape the hierarchical and governance structure of firms and this often creates conflict of interest among the different levels of firms' hierarchy.

In summary, Coriat calls attention to the complex character of the implementation of organisational innovation: "Organizational innovation can only fully materialize if its systemic dimension is totally recalled and taken into account. We mean that a 'local' change (concerning one aspect of the division and coordination of labour), may very well lead to no positive results, but even to supplementary disfunctions if the organization is not adapted and made coherent with the locally introduced changes" (ib. id. p. 16.).

We intend to stress the rather problematic character of the distinction between "product" and "process" innovation in the case of the service sector innovation. In this sector, services are used or consumed at the point of the production. The various waves of the CIS do not pay attention to the significant differences between the manufacturing and the service sectors (Beyhan - Dayar - Findik - Tandogan, 2009: p. 4.). Until know, there is no consent among the representatives of the "assimilation", "dissimilarity" or "synthesis" approaches aimed to better understand innovation in the service sector.

In spite of the experiences of several national innovation surveys (e.g. the Danish DISKO surveys) on the key role of "knowledge absorptive capacity" in an innovative organisation, until now this dimension of innovation has been left out of the existing organisational innovation surveys (including the CIS). This capacity in an organisation is not identical with the formal qualification which is the by-product of "learning as acquisition". 9 In relation to the knowledge absorptive capacity of the organisation, instead of solely insisting on the role of formal training "...what really matters is the ability to deploy qualifications in the job situation. This makes competence an important concept, especially when it relates to the qualities of social capital as cooperation capacity and communication skills internally between different functions, and extremely towards various actors. What the learning organisation requires is a triad of formal education, competence and social capital" (Nielsen, 2006: p. 97.). 


\section{Endnotes}

* The project was financially supported by grant of TÁMOP-4.2.2./ B-10/1.

${ }^{1}$ Valeyre et al. (2009: p. 23.)

${ }^{2}$ Coriat, B. (2001): During the literature review, we used an earlier version of this paper available at http://www.lem.sssup.it/Dynacom/files/D04_0.pdf

${ }^{3}$ Coriat refers here to the seminal work of March and Simon (1993) in which the authors defined the notion of co-ordination as managing and processing information, knowledge and (conflicting) interests.

${ }^{4}$ In spite of the fact that the questions were not the same, the comparison was methodologically correct as both are large-scale European cross-sector surveys measuring changes with retrospective questions.

${ }^{5}$ DISKO is a Danish employer-oriented organisational survey aimed to identify and assess the strengths and the weaknesses of the Danish Innovation System in an international perspective. Until now, at least four waves of the survey were carried out by the Aalborg University and the Statistics Denmark (Information provided by Peter Nielsen, Aalborg University).

${ }^{6}$ The first EWCS was carried out in 1990-1991 covering 12 EU member states that made up the European Union at that time. Our analysis focuses on the following three waves of the surveys: 2000 - 2001, 2005 and 2010. The last three surveys covered the Post-Socialist countries, too. "The survey sample is representative of persons in employment (employees and self-employed), aged 15 years and over, resident in each of the surveyed countries. ... The survey sample followed a multi-stage, stratified and clustered design with a 'random walk' procedure for the selection of the respondents" (Valeyre et al., 2009: p. ix.).

${ }^{7}$ The county groups are as follows:

1) Nordic countries: Denmark, Finland, Netherlands and Sweden,

2) Continental countries: Austria, Belgium, Germany, France and Luxemburg,

3) Anglo-Saxon countries: United Kingdom and Ireland,

4) Mediterranean countries: Cyprus, Greece, Italy, Malta, Spain, Portugal,

5) Post-Socialist countries: Bulgaria, Czech Republic, Estonia, Hungary, Lithuania, Latvia, Poland, Romania, Slovenia and Slovakia (Valeyre et al. 2009: p. 22.).

The "Varieties of Capitalism" (VoC) literature represents the theoretical foundation of the country classification. In addition Sapir, A. (2005) Globalization and the Reform of European Social Models, Background Document for the Presentation at ECOFIN Informal Meeting, Manchester, $9^{\text {th }}$ September (BRUEGEL www.bruegel.org).

${ }^{8}$ For example, the so-called "labour process school" makes a distinction between "learning as acquisition" and "learning as participation". "The former refers to a conceptualization, which views learning as a product with a visible, identifiable outcome, often accompanied by certification or proof of attendance. The latter perspective, on the other hand, views learning as a process in which learners improve their work performance by carrying out daily activities" (Felstead, et al. 2008: p. 5.). This classification is similar to the distinction of "formal education" and "competence development" or "situated learning".

\section{References}

Alasoini, T. (2011a): Workplace Development as Part of Broad - based Innovation Policy: Exploiting and Exploring Three Types of Knowledge, Nordic Journal of Working Life Studies, Vol. 1., No. 1, p. 23-43.

Alasoini, T. (2011b): Learning network as an infrastructure for the creation and dissmination of workplace innovation: an introduction. in: Alasoini, T. - Lahtonen, M. - Rouhiainen, N. -Sweins, Ch. - Hulkko-Nyman, K. - Spanger, T. (eds.): Linking Theory and Practice (Learning Networks at the Service of Workplace Innovation), Helsinki: TYKES Reports 75, p. 13-30.

Arundel, A. (2010): Organisational Innovation in the European Community Innovation Survey (CIS), Maastricht: UNU-MERIT, p. 12.

Arundel, A. - Lorenz, E. - Lundvall, B-A. - Valeyre, A. (2006): The organisation of work and innovative performance: a comparison of the EU-15'. paper presented at the Statistics Canada Blue Sky II Indicators Conference, Ottawa, Canada, October 2006

Basset, J. - Miles, I. - Thénint, H. (2011): Innovation Unbound: Changing innovation locus, changing policy focus. Versailles, France: LLA

Beyhan, B. - Daywr, E. - Findik, D. -Tandogan, S. (2009): Comments and Critics on Discrepancies between Oslo Manual and the Community Innovation Survey in Developed and Developing Countries. Ankara: Sciences and Technology Policies Research Centre (TEKPOL) - Middle East Technical University, p. 11. (http://stp. metu.edu.tr)

Boden, M. - Miles, I. (eds.): Services and the KnowledgeBased Economy. London, New York: Routledge

Chikán A. - Czakó E. - Kazainé Ó. A. (2006): Gazdasági versenyképességünk vállalati nézôpontból - Versenyben a világgal, 2004-2006 (The Hungarian economic competitiveness from an enterprise point of view Competing with the world). Research programme (Final study). Budapest: Budapesti Corvinus Egyetem, Vállalatgazdaságtani Intézet Versenyképességi Kutatóközpont

Coriat, B. (2001): Organizational innovations in European firms: A critical overview of the survey evidence. in: D. Archibugi and B-Å. Lundvall (eds.): The Globalizing Learning Economy. Oxford: Oxford University Press, p. $195-218$.

Dallago, B. (2010): SME Policy and Competitiveness in Hungary. OPENLOC Research Project - Autonomous Province of Trento, p. 22.

Fagerberg, J. (2006): Innovation (A Guide to the literature). in: Fagerberg, J. - Mowery, D. C. - Nelson, R. R. (eds.): The Oxford Handbook of Innovation, Oxford: Oxford University Press, p. 1-26.

Felstead, A. - Gallie, D. - Green, F. - Zhou, Y. (2008): Employee Involvement, the Quality of Training and the Learning Environment: An Individual Level Analysis. 
(Paper submitted for publication in the International Journal of Human Resource Management)

Lam, A. (2005): Organizational innovation. in: Fagerberg, J. - Mowery, D. C. - Nelson, R. R. (eds.): The Oxford Handbook of Innovation. Oxford: Oxford University Press, p. 115-147.

Lundvall, B-A. (2002): The University in the Learning Economy. Aalborg University: DRUID Working Paper No. 02-06.

Makó, Cs. - Csizmadia, P. - Illéssy, M. - Iwasaki, I. - Szanyi, M. (2011): Organizational Innovation and Knowledge Use Practice: Cross-Country Comparison, (Hungarian versus Slovak Business Service Sector). Tokyo: Institute of Economic Research - Hitotsubashi University, Discussion Paper Series, B. No. 38, January

Makó Cs. - Illéssy M. - Csizmadia P. (2008): A munkahelyi innovációk és a termelési paradigmaváltás kapcsolata: A távmunka és a mobil munka példája. Közgazdasági Szemle, LV. évf. december, p. 1075-1093.

March, J. - Simon, A. J. (1993): Organisation Revisited, Industrial and Corporate Change, 2, p. 299-316.

MEADOW Guidelines (Measuring the Dynamics of Organisation of Work) (2010): Project funded within the 6th Framework Programme of the European Commission's DG Research, Grigny (France): DOMIGRAPHIC

Nielsen, P. (2006): The Human Side of Innovation Systems (Innovation, New Organization Forms and Competition Building in a Learning Perspective). Aalborg: Aalborg University Press
OECD (2008): OECD Review of Innovation Policy: HUNGARY (2008). Paris: OECD (www.oecd.org/ publishing/corrigenda)

OECD (2005): OSLO Manual (The Measuring of Scientific and Technological Activities) Guidelines for Collecting and Interpreting Innovation Data ( $3^{\text {rd }}$ Edition) (2005) Joint Publication of OECD and Eurostat, Paris: OECD

Ramioul, M. - Huys, R. (2007): Comparative Analysis of Organizational Surveys in Europe, Work Organisation and Restructuring in the Knowledge Society - EU-6th FP - WORKS-CIT3-CT-2005. Leuven: Institute for Advanced Studies (HIVA)

Schumpeter, J. (1950): The Process of Creative Destruction. in: Shcumpeter (ed.): Capitalism, Socialism and Democracy, $3^{\text {rd }}$ ed., London: Allen and Unwin

Schumpeter, J. (1966): Invention and Economics. Cambridge, Mass.: Harvard University Press

Szerb L. (2010): Vállalkozások, vállalkozási elméletek, vállalkozások mérése és a Globális Vállalkozási és Fejlődési Index. Bp.: Akadémiai Doktori Disszertáció, szept. Szunyogh, Zs. (2011): Az innováció mérésének módszertani kérdései. Statisztikai Szemle, 88. évf. 5. sz., p. 492-507.

Valeyre, A. - Lorenz, E. - Cartron, D. - Csizmadia, P. Gollac, M. - Illéssy, M. - Makó, Cs. (2009): Working Conditions in the European Union: Work Organisation, Luxemburg: Office for Official Publications of the European Communities

Article provided: 2012. 6.

Article accepted: 2012. 11. 